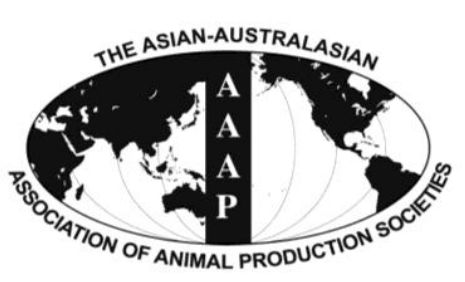

Open Access

Asian Australas. J. Anim. Sci.

Vol. 27, No. 7 : 1026-1034 July 2014

http://dx.doi.org/10.5713/ajas.2013.13775

pISSN 1011-2367 elSSN 1976-5517

\title{
Fatty Acid Composition and Sensory Characteristics of Eggs Obtained from Hens Fed Flaxseed Oil, Dried Whitebait and/or Fructo-oligosaccharide
}

\author{
Haechang Yi, Keum Taek Hwang*, Joe M. Regenstein ${ }^{1}$, and Sung Woo Shin ${ }^{2}$ \\ Department of Food and Nutrition, Research Institute of Human Ecology, \\ Seoul National University, Seoul 151-742, Korea
}

\begin{abstract}
This study was conducted to assess the effects of flaxseed oil and dried whitebait as a source of $\omega-3$ fatty acids $(\omega-3$ FA), which could be used to produce eggs enriched with $\omega-3$ FA, and of fructo-oligosaccharide (FOS) as a source of prebiotics on performance of hens (commercial Hy-Line Brown laying hens), and FA composition, internal quality, and sensory characteristics of the eggs. Dietary FOS increased egg weight. The amounts of $\alpha$-linolenic (ALA), eicosapentaenoic (EPA) and docosahexaenoic acids (DHA) in the eggs from the hens fed the flaxseed oil alone or flaxseed oil+dried whitebait diets were higher than those of the control. Hedonic scores for off-flavor, fishy flavor, buttery taste and overall acceptability of the eggs from the hens fed the diet containing flaxseed oil+ dried whitebait were lower $(\mathrm{p}<0.05)$ than those of the control. Overall acceptability of the eggs from the hens fed the diet containing soybean oil+dried whitebait was lower $(\mathrm{p}<0.05)$ than that of the control. However, all the sensory attributes of the eggs from the hens fed the diet containing flaxseed oil, dried whitebait and FOS were not significantly different from those of the control. These results confirmed that flaxseed oil increases the ALA content in the eggs and a combination of flaxseed oil and dried whitebait increases EPA and DHA in the eggs. Of significance was that addition of FOS to the flaxseed oil+dried whitebait diet improves the sensory characteristics of the eggs enriched with $\omega-3$ FA. (Key Words: Flaxseed Oil, Dried Whitebait, Fructo-oligosaccharide, Egg Enriched with $\omega-3$ Fatty Acid, Brown Laying Hens)
\end{abstract}

\section{INTRODUCTION}

The lipid profile of eggs can be modified by the inclusion of specific oils such as fish oil and flaxseed oil in the diet of laying hens (Shapira et al., 2008; Souza et al., 2008). A proposal from the European Commission's Scientific Panel (European Food Safety Authority, 2005) established a minimal $\omega-3$ fatty acids (FA) content of 300 $\mathrm{mg} / 100 \mathrm{~g}$ egg weight to allow commercial eggs to be labeled as 'sources' of $\omega-3$ FA. The use of marine oils to generate eggs enriched with $\omega-3$ FA has been done successfully (Gonzalez-Esquerra and Leeson, 2001).

\footnotetext{
* Corresponding Author: Keum Taek Hwang. Tel: +82-2-8802531, Fax: +82-2-884-0305, E-mail: keum@snu.ac.kr

${ }^{1}$ Department of Food Science, Cornell University, Ithaca, NY 14853-7201, USA.

${ }^{2}$ Haitnimnara Co., Hwaseong 445-892, Korea.

Submitted Dec. 3, 2013; Revised Jan. 27, 2014; Accepted Feb. 18, 2014
}

However, the use of marine/fish meals and oils in laying hen diets has raised concerns about 'fishy odors' and 'fishy off-flavors', which are considered to be the major undesirable side-effects when including high $\omega$-3 FA levels in the diets fed to hens (Parpinello et al., 2006). Dietary additions of vitamin $\mathrm{E}$ and rosemary extracts as antioxidants have been tested with eggs enriched with $\omega-3$ FA to eliminate the undesirable flavors (Scheideler et al., 1997; Galobart et al., 2001).

Prebiotics are defined as non-digestible food/feed ingredients that beneficially affect the host by selectively stimulating the growth and/or activity of one or a limited number of bacterial species already residing in the intestines (Gibson and Roberfroid, 1995). Among prebiotics, fructooligosaccharides (FOS) have been extensively studied for their ability to improve poultry health and performance. Chen et al. (2005) reported that dietary oligofructose and inulin increased egg production and feed efficiency of layers without impairing egg quality. In addition, Chen and

Copyright $@ 2014$ by Asian-Australasian Journal of Animal Sciences This is an open-access article distributed under the terms of the Creative Commons Attribution Non-Commercial License (http://creativecommons.org/licenses/by-nc/3.0/), which permits unrestricted non-commercial use, distribution, and reproduction in any medium, provided the original work is properly cited. 
Chen (2004) observed that oligofructose or inulin promoted the bird's health and improved eggshell quality. The addition of oligosaccharides in animal feed is suggested to improve the sensory quality of the eggs by manipulating the composition of the intestinal flora, stimulating gut integrity, affecting nitrogen metabolism, and reducing offensive fecal odor (Flickinger et al., 2003). Fructans are considered to inhibit the production of protein-fermentative end-products (excreta odor components) (Gibson and Roberfroid, 1995). However, no information was available on the influence of supplementation with FOS on the sensory qualities of eggs enriched with $\omega-3$ FA.

Thus, the aim of this study was to examine the effects of flaxseed oil, dried whitebait and/or FOS supplementation in diets of hens on performance of hens, and FA composition, internal quality, and sensory characteristics of egg.

\section{MATERIALS AND METHODS}

\section{Bird housing and experimental protocol}

One hundred and forty 80-wk-old brown laying hens (Hy-Line Brown, Hy-Line International, Dallas Center, IA, USA) were used, and the experiment was conducted for four wk (August, 2012) in Happy Shinsun Farm (Sejong, Korea). Hens were assigned randomly to one of seven dietary treatments as described later and each group of 20 birds was kept in an open hen house ( $3 \mathrm{~m} \times 5 \mathrm{~m} \times 3 \mathrm{~m}$ height) with dirt floor and a roof. The birds had approximately 0.75 $\mathrm{m}^{2} /$ hen of floor space under natural environment with light from sunrise to sunset giving a photoperiod of about $14 \mathrm{~h}$ light and $10 \mathrm{~h}$ darkness. Feed was provided in a fixed amount $(120 \mathrm{~g} / \mathrm{d} / \mathrm{hen})$ and was fully consumed during the experimental period. Water was provided for ad libitum consumption. All the procedures for this study were approved by the Institutional Animal Care and Use Committee at Seoul National University (IACUC number: SNU-120914-1).

\section{Diets}

The basal diet was obtained from Nonghyup Feed Co. (Seoul, Korea) and was identical to the diet that the birds had been consuming prior to the experiments. The ingredients in the basal diet were not fully disclosed by the producer except that the main ingredients were corn, wheat meal and soybean meal. Some of the details of the diet can be found in Table 1. Flaxseed (Linum usitatissimum, Brown) oil was obtained from Haitnimnara Co. (Hwaseong, Korea). Soybean oil (Sajohaepyo Co., Seoul, Korea) and sun-dried whitebait (Salangichthys microdon, proximate composition is shown in Table 1) (In-a Feed, Seocheon, Korea) were purchased from a local market. The FOS containing $55 \%$ fructo-oligosaccharide, $17.5 \%$ fructose, $17.5 \%$ glucose and $10 \%$ sucrose (based on the
Table 1. Proximate composition of the basal diet and the dried whitebait $(\%, w / w)$

\begin{tabular}{lcc}
\hline & Basal diet & Dried whitebait \\
\hline Moisture & $11.9 \pm 0.8^{1}$ & $19.7 \pm 1.2$ \\
Crude fat & $4.3 \pm 0.5$ & $10.7 \pm 0.4$ \\
Crude protein & $15.2 \pm 0.6$ & $53.0 \pm 0.7$ \\
Crude fiber & $2.0 \pm 0.1$ & $0.3 \pm 0.1$ \\
Crude ash & $7.9 \pm 0.4$ & $13.8 \pm 0.3$ \\
Calcium $^{2}$ & 3.3 & - \\
Phosphorus $^{2}$ & 1.0 & - \\
Methionine+cysteine $^{2}$ & 0.6 & - \\
${\text { Metabolic energy }(\mathrm{kcal} / \mathrm{kg})^{2}}^{{ }^{1} \text { Data are reported as the average }}$ & 2,740 & - \\
replicates. & & \\
${ }^{2}$ Provided by the feed manufacturer. &
\end{tabular}

manufacturer's analysis) on a dry basis was obtained from Samyang Genex Co. (Seoul, Korea). The diets were formulated to meet the nutrient requirements of laying hens consuming $120 \mathrm{~g}$ of feed per day, which was based on suggestions of the National Research Council (NRC, 1994). The hens were fed a basal diet with $1.5 \%$ soybean oil (control, C), $1.5 \%$ flaxseed oil (T1), $1.5 \%$ soybean oil+ $1.5 \%$ FOS (T2), $1.5 \%$ flaxseed oil $+1.5 \%$ FOS (T3), $1.5 \%$ soybean oil $+1.5 \%$ dried whitebait (T4), $1.5 \%$ flaxseed oil+ $1.5 \%$ dried whitebait (T5) or $1.5 \%$ flaxseed oil $+1.5 \%$ dried whitebait+1.5\% FOS (T6).

\section{Diet and egg analyses}

Feed samples (basal diet and dried whitebait) and egg samples were analyzed for moisture (AOAC 920.36), crude fat (AOAC 920.39), crude protein (AOAC 984.13), crude fiber (AOAC 962.09) and crude ash (AOAC 942.05) according to AOAC methods (1995). The $\mathrm{pH}$ of the egg was measured after diluting the sample with 9 volumes of deionized distilled water. Total cholesterol of the egg samples were determined according to Fenton and Sim (1991) using an Agilent 6890 gas chromatograph (Palo Alto, CA, USA) equipped with a capillary column (HP-1, 30 $\mathrm{m} \times 0.22 \mathrm{~mm} \times 0.33 \mu \mathrm{m}$, Hewlett-Packard, Waldbronn, Germany). The oven was programmed with an initial temperature of $260^{\circ} \mathrm{C}$ for $5 \mathrm{~min}$, to $280^{\circ} \mathrm{C}$ at $4^{\circ} \mathrm{C} / \mathrm{min}$, held for $10 \mathrm{~min}$. Helium was used as the carrier gas at a flow rate of $2 \mathrm{~mL} / \mathrm{min}$. A split injector with 50:1 (v/v) split ratio was used. The temperatures of the injector and detector (flame ionization detector) were $270^{\circ} \mathrm{C}$ and $290^{\circ} \mathrm{C}$, respectively. The quantity of the cholesterol was determined using standard cholesterol (Sigma-Aldrich, St. Louis, MO, USA) and squalene (Supelco, Bellafonte, PA, USA) was used as the internal standard for the cholesterol quantification.

The FA composition of the lipids in the egg yolks was determined using an in situ transesterification procedure (Park and Goins, 1994), which was a modification of the AOCS Official Methods (1980) for FA methyl ester 
(FAME) preparation from fats and oils. The FA composition was determined using the Agilent 6890 gas chromatograph equipped with a capillary column (DB-23, $30 \mathrm{~m} \times 0.25$ $\mathrm{mm} \times 0.25 \mu \mathrm{m}, \mathrm{J} \& \mathrm{~W}$ Scientific, Folsom, CA, USA). The oven was programmed at an initial temperature of $50^{\circ} \mathrm{C}$ for $1 \mathrm{~min}$, to $175^{\circ} \mathrm{C}$ at $25^{\circ} \mathrm{C} / \mathrm{min}$, to $230^{\circ} \mathrm{C}$ at $4^{\circ} \mathrm{C} / \mathrm{min}$, held for $5 \mathrm{~min}$, and to $250^{\circ} \mathrm{C}$ at $25^{\circ} \mathrm{C} / \mathrm{min}$, held for $3 \mathrm{~min}$. The temperatures of the injector and detector (flame ionization detector) were $250^{\circ} \mathrm{C}$ and $280^{\circ} \mathrm{C}$, respectively. Helium was used as the carrier gas at a flow rate of $2 \mathrm{~mL} / \mathrm{min}$ with an injection split ratio of 30:1 (v/v). Peak identification and quantification were performed with reference to the retention times and peak areas as weight percent of a mixture of standard FAME (Supelco 37-component FAME mix, Supelco, Bellafonte, PA, USA). The individual FA was identified by comparing the retention times of $\mathrm{FA}$ to those of external reference mixtures (GLC 3C, 4C, 7C, 8C, 12C, and 20A; $\mathrm{Nu}$ Chek Prep, Inc., Elysian, MN, USA). The results were expressed as \% of total FA. Prior to the analysis the feed samples and eggs were stored in the dark at $4{ }^{\circ} \mathrm{C}$.

\section{Collection of eggs}

Collecting eggs daily from the floor, the weight (g) of each egg and the total egg production (\%) of each group was obtained. Daily egg mass $(\mathrm{g} / \mathrm{d})$ during the $4 \mathrm{wk}$ was calculated as the average egg production (\%)×average egg weight $(\mathrm{g})$. Feed intake was recorded every day and the feed conversion ratio was calculated as feed intake/egg mass $(\mathrm{g} / \mathrm{g})$. All the data were expressed as the mean values for the entire experimental period. During the final 3 days of the study, eggs were randomly collected for FA analysis, egg quality measurements and sensory evaluation. Sensory evaluation was completed within 7 days after the eggs had been laid. Prior to the sensory evaluation the eggs were stored in the dark at $4{ }^{\circ} \mathrm{C}$.

\section{Egg quality}

Albumen height was measured and the Haugh unit was calculated as $100 \log \left(\mathrm{H}_{\mathrm{A}}+7.57-1.7 \mathrm{~W}_{\mathrm{E}}^{0.37}\right)$, where $\mathrm{H}_{\mathrm{A}}$ is maximum albumen height and $\mathrm{W}_{\mathrm{E}}$ is egg weight (Haugh, 1937). Eggshell thickness was measured near the equator of the egg, using an electronic micrometer (QCT Device, TSS, York, England). Twenty eggs from each treatment were collected for the measurement of eggshell breaking strength, using an Instron Testing Machine (Model 5542, Instron Ltd., High Wycombe, England), equipped with a 500 Newton load cell (Hamilton, 1982). The egg was placed horizontally for measurements. The eggs were compressed at a constant crosshead speed of $10 \mathrm{~mm} / \mathrm{min}$ and the breaking strength was determined at the moment of the eggshell fracture. A 35 $\mathrm{mm}$ diameter plate was used as a compression device.

\section{Sensory evaluation}

Sensory characteristics were evaluated by 15 graduate students (ages 20 to $30 \mathrm{yr}$ old, 7 male and 8 female) in the laboratory who had taken a sensory evaluation course. Ten eggs per treatment produced during the final 3 days of the experimental period were randomly selected. They were placed in boiling water $(10 \mathrm{~L})$ for $15 \mathrm{~min}$, and then cooled using running tap water. Shells were immediately removed and each egg was cut through the center into quarters, and then served. All the samples were evaluated immediately after preparation was completed.

Organoleptic characteristics of the eggs were recorded on a seven point hedonic scale $(1=$ dislike extremely; $7=$ like extremely) with ascending ratings for the desired attributes of color, off-flavor, fishy flavor, buttery taste and overall acceptability. Off-flavor (the presence of something agreeable or disagreeable differing from the typical egg odor/taste) and fishy flavor (the presence of fishy odor/taste) were defined with the panelists and 'higher scores were assigned to the samples with the lower offflavor and fishy flavor'. Egg samples were coded with three digit randomized numbers. The samples were served to the panelists in individual booths on white plastic plates in a random order. A plate containing seven samples in a random order was presented to the panelists to evaluate. Cold water was also provided for rinsing their mouths before testing each sample. This procedure was done in duplicate with each panelist. They evaluated the eggs in two different sessions. Thus, the trained panel was able to evaluate more complex factors but was still reflecting their personal opinion.

\section{Statistical analysis}

Analysis of variance (ANOVA) was done using the SPSS package (SPSS Version $12.0 \mathrm{~K}$ for Windows, SPSS Inc., Chicago, IL, USA). Where significant differences $(\mathrm{p}<0.05)$ were detected, Duncan's multiple range test was used to compare treatment means.

\section{RESULTS AND DISSCUSSION}

\section{Diet and egg composition}

Proximate composition of the basal diet and the dried whitebait are shown in Table 1 . The crude fat contents of the basal diet and dried whitebait were $4.3 \%$ and $10.7 \%$, respectively. Proximate composition, $\mathrm{pH}$ and cholesterol of the eggs from the hens fed the diets with flaxseed oil, dried whitebait and/or FOS are shown in Table 2. No differences were observed in the proximate composition of the eggs from the hens fed the different diets $(p>0.05)$. Egg cholesterol concentration was not significantly $(p>0.05)$ affected by a diet containing flaxseed as previously reported for other oilseeds (Milinsk et al., 2003). Frank (1999) 
Table 2. Proximate composition, $\mathrm{pH}$ and total cholesterol of the eggs from hens fed diets with flaxseed oil, dried whitebait and/or fructooligosaccharide (FOS)

\begin{tabular}{lrrrrrrr}
\hline & \multicolumn{1}{c}{$\mathrm{C}^{2}$} & \multicolumn{1}{c}{$\mathrm{T} 1$} & \multicolumn{1}{c}{$\mathrm{T} 2$} & $\mathrm{~T} 3$ & $\mathrm{~T} 4$ & $\mathrm{~T} 5$ & $\mathrm{~T} 6$ \\
\hline Moisture (\%) & $77.0 \pm 1.3^{1,3}$ & $76.7 \pm 1.8$ & $77.3 \pm 2.1$ & $77.6 \pm 1.9$ & $76.7 \pm 2.0$ & $76.1 \pm 0.7$ & $75.4 \pm 1.6$ \\
Crude fat (\%) & $6.3 \pm 1.0$ & $6.7 \pm 0.5$ & $6.3 \pm 0.8$ & $7.3 \pm 1.1$ & $7.6 \pm 0.5$ & $7.6 \pm 0.4$ & $7.7 \pm 0.7$ \\
Crude protein (\%) & $12.3 \pm 0.4$ & $12.2 \pm 0.3$ & $12.0 \pm 0.2$ & $11.2 \pm 0.8$ & $12.1 \pm 0.4$ & $12.2 \pm 0.4$ & $12.5 \pm 0.5$ \\
Ash (\%) & $0.8 \pm 0.0$ & $0.8 \pm 0.1$ & $0.8 \pm 0.0$ & $0.8 \pm 0.1$ & $0.8 \pm 0.1$ & $0.9 \pm 0.0$ & $0.9 \pm 0.1$ \\
$\mathrm{pH}$ & $7.9 \pm 0.2$ & $8.0 \pm 0.1$ & $8.0 \pm 0.2$ & $7.9 \pm 0.0$ & $7.8 \pm 0.1$ & $7.7 \pm 0.1$ & $7.8 \pm 0.1$ \\
Total cholesterol (mg/100 g) & $227.0 \pm 10.7$ & $241.0 \pm 5.9$ & $221.0 \pm 7.8$ & $244.0 \pm 6.6$ & $229.0 \pm 7.9$ & $247.0 \pm 10.1$ & $244.0 \pm 8.4$ \\
\hline
\end{tabular}

${ }^{1}$ Data are reported as average values \pm standard deviation of three replicates obtained during the final 3 days of the experiment (one sample per group $=3$ pooled eggs).

${ }^{2} \mathrm{C}$, basal diet with $1.5 \%$ soybean oil; T1, basal diet with $1.5 \%$ flaxseed oil; T2, basal diet with $1.5 \%$ soybean oil+1.5\% FOS; T3, basal diet with $1.5 \%$ flaxseed oil+1.5\% FOS; T4, basal diet with $1.5 \%$ soybean oil $+1.5 \%$ dried whitebait; T5, basal diet with $1.5 \%$ flaxseed oil $+1.5 \%$ dried whitebait; and T6, basal diet with $1.5 \%$ flaxseed oil $+1.5 \%$ dried whitebait $+1.5 \%$ FOS.

${ }^{3}$ Not significant.

reported that dietary inulin in layers reduced egg cholesterol. However, the cholesterol level in the eggs was not affected by the different diets in this study.

\section{Laying performance and egg quality}

No mortalities were observed during the experimental period. Laying performance and egg quality are presented in Table 3. The eggs from the hens fed the T6 diet were the heaviest $(\mathrm{p}<0.05)$. Gonzalez-Esquerra and Leeson (2000) reported that hens fed a diet with fish oil laid heavier eggs. In contrast, Scheideler and Froning (1996) reported that hens fed flaxseed diet laid lighter eggs. The eggs of the T3 and T6 diet were heavier than those of the $\mathrm{C}$ diet, suggesting that supplementation with FOS in the diet for the hens may increase egg weight. These results agree with a previous study (Chen et al., 2005) which reported that the addition of $1.0 \%$ oligofructose increased $(p<0.05)$ the weekly total egg weight per bird.
Egg production was lower in the groups fed the T2 and T6 diets than in the other groups. T3 diet group had the highest egg production. Scheideler and Froning (1996) reported a positive effect on egg production after feeding flaxseed at the 5\%,10\%, and $15 \%$ levels for $6 \mathrm{wk}$. Aymond and Van Elswyk (1995) observed a decrease in egg production in hens fed a diet containing $15 \%$ flaxseed as early as 2 wk after feeding. Chen et al. (2005) reported that adding oligofructose and inulin improved layer performance. Also, Park and Park (2012) reported that inulin oligosaccharides improved layer performance. On the other hand, Yildiz et al. (2006) reported that laying performance was not affected by supplementation of Jerusalem artichoke as an inulin source.

The albumen height and Haugh unit of the eggs from the hens fed the T2 diet were significantly higher $(\mathrm{p}<0.05)$ than those of the eggs from the other treatment groups. Chen et al. (2005) reported that Haugh units of eggs were

Table 3. Laying performance of the hens fed diets with flaxseed oil, dried whitebait and/or fructo-oligosaccharide (FOS) and their egg quality

\begin{tabular}{|c|c|c|c|c|c|c|c|}
\hline & $\mathrm{C}^{3}$ & T1 & $\mathrm{T} 2$ & T3 & $\mathrm{T} 4$ & T5 & T6 \\
\hline$\overline{\text { Egg weight }(\mathrm{g})^{1}}$ & $62.5 \pm 1.3^{\mathrm{c}}$ & $63.8 \pm 1.5^{\mathrm{b}}$ & $63.8 \pm 0.9^{\mathrm{b}}$ & $64.8 \pm 1.7^{\mathrm{a}}$ & $65.4 \pm 1.7^{\mathrm{a}}$ & $63.9 \pm 1.9^{\mathrm{b}}$ & $65.6 \pm 1.9^{\mathrm{a}}$ \\
\hline Egg production $(\%)$ & $88.2 \pm 5.6^{\mathrm{ab}}$ & $87.3 \pm 5.1^{\mathrm{ab}}$ & $80.5 \pm 9.9^{c}$ & $90.6 \pm 7.3^{\mathrm{a}}$ & $85.6 \pm 6.3^{\mathrm{b}}$ & $89.0 \pm 5.7^{\mathrm{ab}}$ & $80.8 \pm 9.2^{\mathrm{c}}$ \\
\hline Egg mass $(g / d)$ & $55.1 \pm 3.8^{\mathrm{bc}}$ & $55.7 \pm 3.3^{\mathrm{bc}}$ & $51.4 \pm 6.5^{\mathrm{d}}$ & $58.8 \pm 5.4^{\mathrm{a}}$ & $56.0 \pm 4.4^{\mathrm{b}}$ & $56.9 \pm 4.4^{\mathrm{ab}}$ & $53.1 \pm 6.6^{\mathrm{cd}}$ \\
\hline Feed intake $(\mathrm{g} / \mathrm{d} / \mathrm{h})$ & $120.0 \pm 0.0$ & $120.0 \pm 0.0$ & $120.0 \pm 0.0$ & $120.0 \pm 0.0$ & $120.0 \pm 0.0$ & $120.0 \pm 0.0$ & $120.0 \pm 0.0$ \\
\hline $\begin{array}{l}\text { Feed conversion ratio } \\
\text { ( } \mathrm{g} \text { feed/g egg) }\end{array}$ & $2.2 \pm 0.2^{\mathrm{bc}}$ & $2.2 \pm 0.1^{\mathrm{c}}$ & $2.4 \pm 0.4^{\mathrm{a}}$ & $2.1 \pm 0.2^{\mathrm{c}}$ & $2.2 \pm 0.2^{\mathrm{c}}$ & $2.1 \pm 0.2^{\mathrm{c}}$ & $2.3 \pm 0.3^{\mathrm{ab}}$ \\
\hline Albumen height $(\mathrm{mm})^{2}$ & $6.2 \pm 0.9^{c}$ & $6.5 \pm 0.8^{\mathrm{bc}}$ & $7.1 \pm 0.8^{\mathrm{a}}$ & $6.2 \pm 0.7^{\mathrm{c}}$ & $7.0 \pm 0.7^{\mathrm{a}}$ & $6.6 \pm 1.0^{\mathrm{abc}}$ & $6.5 \pm 1.0^{\mathrm{bc}}$ \\
\hline Haugh units (HU) & $77.9 \pm 6.3^{\mathrm{bc}}$ & $79.4 \pm 6.5^{\mathrm{bc}}$ & $83.7 \pm 5.3^{\mathrm{a}}$ & $76.9 \pm 5.1^{\mathrm{c}}$ & $82.9 \pm 4.2^{\mathrm{ab}}$ & $79.3 \pm 7.2^{\mathrm{bc}}$ & $78.8 \pm 7.1^{\mathrm{bc}}$ \\
\hline $\begin{array}{l}\text { Eggshell thickness } \\
(\mathrm{mm})\end{array}$ & $0.341 \pm 0.0^{\mathrm{ab}}$ & $0.352 \pm 0.0^{\mathrm{a}}$ & $0.347 \pm 0.0^{\mathrm{a}}$ & $0.318 \pm 0.1^{\mathrm{b}}$ & $0.324 \pm 0.0^{\mathrm{b}}$ & $0.344 \pm 0.0^{\mathrm{ab}}$ & $0.336 \pm 0.0^{\mathrm{ab}}$ \\
\hline $\begin{array}{l}\text { Eggshell breaking } \\
\text { strength }\left(\mathrm{g} / \mathrm{cm}^{2}\right)\end{array}$ & $3,587.0 \pm 747$ & $3,478.0 \pm 642$ & $3,386.0 \pm 705$ & $3,322.0 \pm 778$ & $3,205.0 \pm 802$ & $3,691.0 \pm 733$ & $3,264.0 \pm 854$ \\
\hline
\end{tabular}


not $(p>0.05)$ affected by oligofructose or inulin treatment. Eggshell thickness was significantly $(p<0.05)$ different among the treatments. Eggshell thickness was highest in the $\mathrm{T} 1$ and lowest in the T3. However, eggshell breaking strength was not significantly $(\mathrm{p}>0.05)$ different among the treatments. Park and Park (2012) reported that the Haugh unit, eggshell thickness and eggshell breaking strength are higher in inulin oligosaccharide addition group $(250 \mathrm{mg} / \mathrm{kg}$ diet) than those in the control group. In the present study, however, flaxseed oil and fish meal as well as FOS did not affect the eggshell thickness and eggshell breaking strength of the egg. One difference in this experiment was that the birds were in a late stage of the egg production cycle.

\section{Fatty acids composition}

The FA compositions of the basal diet, soybean oil, flaxseed oil and dried whitebait used for this study are shown in Table 4. Flaxseed oil was rich in $\alpha$-linolenic acid (ALA) (48.4\%) and dried whitebait was rich in eicosapentaenoic (EPA) (20.9\%) and docosahexaenoic acids (DHA) (20.4\%), which were hardly present in the basal diet and soybean oil.

The FA compositions of the lipids in the eggs are shown in Table 5. The ALA in the eggs from the hens fed the T1 and T5 diets were 6.8 and 5.9 times, respectively, higher than that of the control eggs. The flaxseed oil in the diet resulted in the large increase in ALA concentration in the eggs. The ALA in the eggs from the hens fed the diet containing dried whitebait without flaxseed oil (T4) was as low as that of the C diet. Souza et al. (2008) reported similar results, where higher levels of this FA in the eggs from the hens fed flaxseed or its oil were observed compared to those with corn, soybean, canola and sunflower oils. The ALA was significantly lower $(p<0.05)$ in the eggs produced by the hens fed the diets of flaxseed oil and/or dried whitebait with FOS (T3 and T6) than in the eggs from the hens fed the diets without FOS (T1 and T5). However, the biological mechanism with respect to how FOS causes less ALA to be found in the eggs is not clear.

The EPA and DHA were significantly higher $(\mathrm{p}<0.05)$ in the eggs produced by the hens fed the T1, T3, T4, T5, and $\mathrm{T} 6$ diets than in the eggs from the hens fed the $\mathrm{C}$ diet. Flaxseed oil does not contain EPA or DHA, but it contains a large amount of ALA, which can be a precursor of EPA and DHA. EPA and DHA in the eggs might also come from the direct deposit of these FA in the diet (e.g., from the fish oil) or from synthesis from precursors such as ALA. The EPA and DHA were the highest in the lipids of the eggs from the hens fed the T5 and T6 diets, respectively. The increase in these FA might be due to the addition of flaxseed oil and dried whitebait in the diet $(\mathrm{p}<0.05)$, while the FOS in the diet had no effect on the levels of these FA. These results

Table 4. Fatty acid composition of basal diet, soybean oil, flaxseed oil and dried whitebait (\% of total fatty acids, w/w)

\begin{tabular}{|c|c|c|c|c|}
\hline Fatty acids & Basal diet & Soybean oil & Flaxseed oil & Dried whitebait \\
\hline Myristic acid (C14:0) & $0.6 \pm 0.0^{1}$ & $0.1 \pm 0.0$ & - & $1.7 \pm 0.0$ \\
\hline Myristoleic acid (C14:1) & - & - & - & - \\
\hline Pentadecanoic acid (C15:0) & $0.1 \pm 0.0$ & - & - & $0.4 \pm 0.0$ \\
\hline Palmitic acid (C16:0) & $16.6 \pm 0.1$ & $10.7 \pm 0.0$ & $4.7 \pm 0.0$ & $22.0 \pm 0.1$ \\
\hline Palmitoleic acid (C16:1) & $0.9 \pm 0.0$ & $0.1 \pm 0.0$ & $0.1 \pm 0.0$ & $4.6 \pm 0.0$ \\
\hline Heptadecanoic acid (C17:0) & $0.2 \pm 0.0$ & - & - & $5.7 \pm 0.0$ \\
\hline cis-10-Heptadecenoic acid (C17:1) & - & - & - & - \\
\hline Stearic acid (C18:0) & $4.9 \pm 0.0$ & $4.6 \pm 0.0$ & $5.1 \pm 0.0$ & $5.7 \pm 0.0$ \\
\hline Oleic acid (C18:1c) & $31.5 \pm 0.1$ & $25.2 \pm 0.0$ & $25.0 \pm 0.1$ & $7.9 \pm 0.0$ \\
\hline Linoleaidic acid (C18:2 $\omega 6 \mathrm{t})$ & - & $1.2 \pm 0.0$ & $0.6 \pm 0.0$ & - \\
\hline Linoleic acid $(\mathrm{C} 18: 2 \omega 6 \mathrm{c})$ & $42.5 \pm 0.1$ & $51.7 \pm 0.1$ & $15.9 \pm 0.0$ & $1.3 \pm 0.0$ \\
\hline$\alpha$-Linolenic acid (C18:3 $\omega 3)$ & $2.0 \pm 0.0$ & $5.8 \pm 0.0$ & $48.4 \pm 0.1$ & $0.7 \pm 0.2$ \\
\hline Arachidic acid (C20:0) & - & $0.4 \pm 0.0$ & $0.2 \pm 0.0$ & $2.1 \pm 0.0$ \\
\hline Eicosadienoic acid (C20:2) & $0.4 \pm 0.0$ & $0.2 \pm 0.0$ & $0.2 \pm 0.0$ & - \\
\hline Heneicosanoic acid (C21:0) & - & - & - & $0.3 \pm 0.0$ \\
\hline Arachidonic acid (C20:4 $\omega 6)$ & - & - & - & $0.8 \pm 0.0$ \\
\hline Eicosapentaenoic acid (C20:5 $\omega 3)$ & $0.3 \pm 0.0$ & - & - & $20.9 \pm 0.2$ \\
\hline Behenic acid (C22:0) & - & $0.5 \pm 0.0$ & - & - \\
\hline Erucic acid (C22:1) & $0.3 \pm 0.0$ & - & - & $2.8 \pm 0.2$ \\
\hline Tricosanoic acid (C23:0) & - & - & - & $0.8 \pm 0.0$ \\
\hline Lignoceric acid (C24:0) & - & - & - & $1.1 \pm 0.0$ \\
\hline Docosahexaenoic acid (C22:6 $\omega 3)$ & - & - & - & $20.4 \pm 0.2$ \\
\hline Nervonic acid (C24:1) & - & - & - & $1.1 \pm 0.0$ \\
\hline
\end{tabular}

${ }^{1}$ Data are reported as average values \pm standard deviation of three replicates. 
Table 5. Fatty acid composition of lipids in the eggs from hens fed diets with flaxseed oil, dried whitebait and/or fructo-oligosaccharide (FOS) $(\%$ of total fatty acids, w/w)

\begin{tabular}{|c|c|c|c|c|c|c|c|}
\hline Fatty acids & $\mathrm{C}^{2}$ & $\mathrm{~T} 1$ & $\mathrm{~T} 2$ & $\mathrm{~T} 3$ & $\mathrm{~T} 4$ & $\mathrm{~T} 5$ & T6 \\
\hline Lauric acid (C12:0) & $0.0 \pm 0.0^{1}$ & $0.0 \pm 0.0$ & $0.0 \pm 0.0$ & $0.0 \pm 0.0$ & $0.0 \pm 0.0$ & $0.1 \pm 0.2$ & $0.0 \pm 0.0$ \\
\hline Myristic acid (C14:0) & $0.4 \pm 0.0^{\mathrm{a}}$ & $0.3 \pm 0.0^{\mathrm{ab}}$ & $0.4 \pm 0.0^{\mathrm{a}}$ & $0.3 \pm 0.0^{\mathrm{ab}}$ & $0.3 \pm 0.0^{\mathrm{ab}}$ & $0.2 \pm 0.1^{\mathrm{b}}$ & $0.4 \pm 0.0^{\mathrm{a}}$ \\
\hline Myristoleic acid (C14:1) & $0.1 \pm 0.1^{\mathrm{a}}$ & $0.1 \pm 0.0^{\mathrm{ab}}$ & $0.1 \pm 0.0^{\mathrm{ab}}$ & $0.1 \pm 0.0^{\mathrm{ab}}$ & $0.1 \pm 0.0^{\mathrm{b}}$ & $0.1 \pm 0.0^{\mathrm{ab}}$ & $0.1 \pm 0.0^{\mathrm{ab}}$ \\
\hline oic acid (C15:0) & $0.1 \pm 0.0$ & $0.1 \pm 0.0$ & $0.1 \pm 0.0$ & $0.1 \pm 0.1$ & $0.1 \pm 0.1$ & $0.1 \pm 0.0$ & $0.1 \pm 0.0$ \\
\hline Palmitic acid (C16:0) & $24.5 \pm 0.6^{\mathrm{a}}$ & $22.3 \pm 0.1^{\mathrm{c}}$ & $24.3 \pm 1.1^{\mathrm{a}}$ & $22.7 \pm 0.2^{\mathrm{c}}$ & $23.8 \pm 0.5^{\mathrm{ab}}$ & $23.0 \pm 0.4^{\mathrm{bc}}$ & $24.0 \pm 0.5^{\mathrm{ab}}$ \\
\hline Palmitoleic acid (C16:1) & $2.9 \pm 0.3^{\mathrm{ab}}$ & $3.0 \pm 0.1^{\mathrm{ab}}$ & $2.9 \pm 0.4^{\mathrm{ab}}$ & $3.0 \pm 0.1^{\mathrm{ab}}$ & $2.6 \pm 0.4^{\mathrm{b}}$ & $3.3 \pm 0.1^{\mathrm{a}}$ & $3.4 \pm 0.3^{\mathrm{a}}$ \\
\hline Heptadecanoic acid (C17:0) & $0.2 \pm 0.0^{\mathrm{ab}}$ & $0.2 \pm 0.0^{\mathrm{ab}}$ & $0.2 \pm 0.0^{\mathrm{ab}}$ & $0.2 \pm 0.0^{\mathrm{ab}}$ & $0.2 \pm 0.0^{\mathrm{a}}$ & $0.2 \pm 0.0^{\mathrm{b}}$ & $0.2 \pm 0.0^{\mathrm{ab}}$ \\
\hline cis-10-Heptadecenoic acid (C17:1) & $0.2 \pm 0.0^{\mathrm{d}}$ & $0.2 \pm 0.0^{\mathrm{ab}}$ & $0.2 \pm 0.0^{\mathrm{bcd}}$ & $0.2 \pm 0.0^{\mathrm{a}}$ & $0.2 \pm 0.0^{\mathrm{cd}}$ & $0.2 \pm 0.0^{\mathrm{abc}}$ & $0.2 \pm 0.0^{\mathrm{bcd}}$ \\
\hline Stearic acid (C18:0) & $8.2 \pm 0.4$ & $8.1 \pm 0.4$ & $8.0 \pm 0.1$ & $7.8 \pm 0.2$ & $8.2 \pm 0.2$ & $7.8 \pm 0.2$ & $7.8 \pm 0.2$ \\
\hline Elaidic acid (C18:1t) & $0.2 \pm 0.2$ & $0.2 \pm 0.2$ & $0.4 \pm 0.1$ & $0.3 \pm 0.0$ & $0.3 \pm 0.1$ & $0.3 \pm 0.0$ & $0.3 \pm 0.0$ \\
\hline Oleic acid $(\mathrm{C} 18: 1 \mathrm{c})$ & $41.1 \pm 1.5^{\mathrm{b}}$ & $42.6 \pm 0.7^{\mathrm{ab}}$ & $41.2 \pm 0.9^{\mathrm{b}}$ & $43.2 \pm 0.9^{\mathrm{a}}$ & $41.3 \pm 0.2^{\mathrm{b}}$ & $42.8 \pm 0.8^{\mathrm{ab}}$ & $42.1 \pm 0.8^{\mathrm{ab}}$ \\
\hline idic acid (C18:2 $\omega 6 \mathrm{t})$ & $0.1 \pm 0.1^{\mathrm{b}}$ & $0.1 \pm 0.1^{\mathrm{b}}$ & $0.3 \pm 0.1^{\mathrm{a}}$ & $0.3 \pm 0.0^{\mathrm{a}}$ & $0.2 \pm 0.0^{\mathrm{ab}}$ & $0.2 \pm 0.0^{\mathrm{ab}}$ & $0.2 \pm 0.0^{\mathrm{ab}}$ \\
\hline Linoleic acid (C18:2 $\omega 6 \mathrm{c})$ & $17.9 \pm 1.6^{\mathrm{a}}$ & $13.9 \pm 0.5^{\mathrm{b}}$ & $17.7 \pm 1.6^{\mathrm{a}}$ & $14.2 \pm 0.4^{\mathrm{b}}$ & $17.3 \pm 1.1^{\mathrm{a}}$ & $13.2 \pm 1.2^{\mathrm{b}}$ & $13.7 \pm 1.1^{\mathrm{b}}$ \\
\hline$\Gamma$-Linolenic acid $(\mathrm{C} 18: 3 \omega 6)$ & $0.1 \pm 0.0^{\mathrm{b}}$ & $0.1 \pm 0.0^{\mathrm{b}}$ & $0.1 \pm 0.1^{\mathrm{a}}$ & $0.1 \pm 0.1^{\mathrm{ab}}$ & $0.1 \pm 0.0^{\mathrm{ab}}$ & $0.1 \pm 0.0^{\mathrm{b}}$ & $0.1 \pm 0.0^{\mathrm{b}}$ \\
\hline$\alpha$-Linolenic acid (C18:3 $\omega 3)$ & $0.6 \pm 0.0^{\mathrm{d}}$ & $4.3 \pm 0.4^{\mathrm{a}}$ & $0.6 \pm 0.1^{\mathrm{d}}$ & $2.9 \pm 0.3^{c}$ & $0.6 \pm 0.0^{\mathrm{d}}$ & $3.8 \pm 0.3^{\mathrm{b}}$ & $2.5 \pm 0.2^{\mathrm{c}}$ \\
\hline 11-Eicosenoic acid (C20:1) & $0.2 \pm 0.0^{\mathrm{a}}$ & $0.2 \pm 0.0^{c}$ & $0.2 \pm 0.0^{\mathrm{a}}$ & $0.2 \pm 0.0^{\mathrm{bc}}$ & $0.2 \pm 0.0^{\mathrm{a}}$ & $0.2 \pm 0.0^{\mathrm{ab}}$ & $0.2 \pm 0.0^{\mathrm{ab}}$ \\
\hline Eicosadienoic acid (C20:2) & $0.2 \pm 0.0^{\mathrm{a}}$ & $0.1 \pm 0.0^{\mathrm{bc}}$ & $0.2 \pm 0.0^{\mathrm{a}}$ & $0.2 \pm 0.0^{\mathrm{bc}}$ & $0.2 \pm 0.0^{\mathrm{a}}$ & $0.1 \pm 0.0^{\mathrm{c}}$ & $0.2 \pm 0.0^{\mathrm{b}}$ \\
\hline cis-8,11,14-Eicosatrienoic acid (C20:3 $\omega 6)$ & $0.2 \pm 0.0^{\mathrm{b}}$ & $0.2 \pm 0.0^{\mathrm{ab}}$ & $0.2 \pm 0.0^{\mathrm{ab}}$ & $0.2 \pm 0.0^{\mathrm{a}}$ & $0.2 \pm 0.0^{\mathrm{ab}}$ & $0.2 \pm 0.0^{\mathrm{ab}}$ & $0.2 \pm 0.0^{\mathrm{a}}$ \\
\hline Arachidonic acid (C20:4 $\omega 6)$ & $1.9 \pm 0.1^{\mathrm{a}}$ & $1.2 \pm 0.0^{\mathrm{de}}$ & $1.9 \pm 0.1^{\mathrm{a}}$ & $1.4 \pm 0.0^{\mathrm{c}}$ & $1.7 \pm 0.1^{\mathrm{b}}$ & $1.1 \pm 0.0^{\mathrm{e}}$ & $1.2 \pm 0.1^{\mathrm{d}}$ \\
\hline cis-11,14,17-Eicosatrienoic acid (C2 & $0.0 \pm 0.0^{\mathrm{b}}$ & $0.1 \pm 0.0^{\mathrm{a}}$ & $0.1 \pm 0.1^{\mathrm{ab}}$ & $0.1 \pm 0.0^{\mathrm{ab}}$ & $0.0 \pm 0.0^{\mathrm{b}}$ & $0.1 \pm 0.0^{\mathrm{a}}$ & $0.1 \pm 0.0^{\mathrm{ab}}$ \\
\hline Eicosapentaenoic acid (C20:5 $\omega 3)$ & $0.0 \pm 0.0^{\mathrm{c}}$ & $0.1 \pm 0.1^{\mathrm{b}}$ & $0.0 \pm 0.0^{\mathrm{c}}$ & $0.1 \pm 0.0^{\mathrm{b}}$ & $0.1 \pm 0.0^{\mathrm{b}}$ & $0.1 \pm 0.0^{\mathrm{a}}$ & $0.1 \pm 0.0^{\mathrm{a}}$ \\
\hline Docosadienoic acid (C22:2) & $0.0 \pm 0.0^{c}$ & $0.2 \pm 0.0^{\mathrm{b}}$ & $0.0 \pm 0.0^{\mathrm{c}}$ & $0.2 \pm 0.0^{\mathrm{b}}$ & $0.3 \pm 0.0^{\mathrm{b}}$ & $0.2 \pm 0.0^{\mathrm{b}}$ & $0.3 \pm 0.0^{\mathrm{a}}$ \\
\hline Lignoceric acid (C24:0) & $0.1 \pm 0.0^{c}$ & $0.3 \pm 0.1^{\mathrm{bc}}$ & $0.1 \pm 0.0^{c}$ & $0.3 \pm 0.1^{\mathrm{b}}$ & $0.2 \pm 0.0^{\mathrm{c}}$ & $0.3 \pm 0.0^{\mathrm{bc}}$ & $0.4 \pm 0.1^{\mathrm{a}}$ \\
\hline Docosahexaenoic acid (C22:6 $\omega 3)$ & $0.9 \pm 0.0^{\mathrm{d}}$ & $2.1 \pm 0.1^{\mathrm{b}}$ & $0.8 \pm 0.0^{\mathrm{d}}$ & $2.0 \pm 0.1^{\mathrm{cb}}$ & $1.8 \pm 0.1^{\mathrm{c}}$ & $2.4 \pm 0.2^{\mathrm{a}}$ & $2.4 \pm 0.2^{\mathrm{a}}$ \\
\hline Total saturated fatty acids & $33.4 \pm 0.6^{\mathrm{a}}$ & $31.4 \pm 0.3^{\mathrm{b}}$ & $33.1 \pm 1.0^{\mathrm{a}}$ & $31.4 \pm 0.4^{\mathrm{b}}$ & $32.9 \pm 0.3^{\mathrm{a}}$ & $31.7 \pm 0.5^{\mathrm{b}}$ & $32.8 \pm 0.6^{\mathrm{a}}$ \\
\hline Total $\omega-3$ fatty acids & $1.5 \pm 0.1^{\mathrm{d}}$ & $6.6 \pm 0.5^{\mathrm{a}}$ & $1.5 \pm 0.0^{\mathrm{d}}$ & $5.0 \pm 0.3^{\mathrm{b}}$ & $2.4 \pm 0.2^{\mathrm{c}}$ & $6.4 \pm 0.2^{\mathrm{a}}$ & $5.1 \pm 0.2^{\mathrm{b}}$ \\
\hline Total $\omega-6$ fatty acids & $20.1 \pm 1.7^{\mathrm{a}}$ & $15.4 \pm 0.5^{\mathrm{b}}$ & $20.3 \pm 1.7^{\mathrm{a}}$ & $16.1 \pm 0.5^{\mathrm{b}}$ & $19.5 \pm 1.0^{\mathrm{a}}$ & $14.7 \pm 1.2^{\mathrm{b}}$ & $15.3 \pm 1.2^{\mathrm{b}}$ \\
\hline$\omega-6 / \omega-3$ fatty acids ratio & $13.5 \pm 0.3^{\mathrm{a}}$ & $2.4 \pm 0.2^{\mathrm{c}}$ & $13.5 \pm 1.3^{\mathrm{a}}$ & $3.2 \pm 0.2^{c}$ & $8.2 \pm 1.0^{\mathrm{b}}$ & $2.3 \pm 0.2^{\mathrm{c}}$ & $3.0 \pm 0.2^{\mathrm{c}}$ \\
\hline
\end{tabular}

${ }^{1}$ Data are reported as average values \pm standard deviation of three replicates obtained during the final 3 days of the experiment (one sample per group $=3$ pooled eggs for each group).

${ }^{2} \mathrm{C}$, basal diet with $1.5 \%$ soybean oil; T1, basal diet with $1.5 \%$ flaxseed oil; T2, basal diet with $1.5 \%$ soybean oil+1.5\% FOS; T3, basal diet with $1.5 \%$ flaxseed oil+1.5\% FOS; T4, basal diet with $1.5 \%$ soybean oil $+1.5 \%$ dried whitebait; T5, basal diet with $1.5 \%$ flaxseed oil+1.5\% dried whitebait; T6, basal diet with $1.5 \%$ flaxseed oil $+1.5 \%$ dried whitebait+1.5\% FOS.

${ }^{\mathrm{a}-\mathrm{e}}$ Means in the same row with different superscripts are significantly different $(\mathrm{p}<0.05)$.

confirm once again the theory of slight de novo synthesis of these long chain polyunsaturated fatty acids from their precursors (Yildiz et al., 2006).

The addition of flaxseed oil and dried whitebait to the diet of the hens gave a $\omega-6 / \omega-3$ FA ratio $(2.3$ to 8.2$)$ in the lipids in the eggs, which was significantly lower $(\mathrm{p}<0.05)$ than the control diet (13.5). However, the $\omega-6 / \omega-3$ FA ratio did not seem to be affected by the addition of FOS. It can be noted that an increase in the $\omega-3$ FA in the diet, especially by combining these two feed sources, might result in a greater reduction in the $\omega-6 / \omega-3$ FA ratio. Total $\omega-3$ FA content in the eggs from hens fed flaxseed oil, dried whitebait and/or FOS diets ranged from 93 to $487 \mathrm{mg} / 100 \mathrm{~g}$ egg weight in this study. Among them, the eggs from the hens fed the T1, T3, T5, and T6 diets contained at least $3 \mathrm{~g}$ $\omega-3 \mathrm{FA} / \mathrm{kg}$ egg weight and thereby meet the criteria suggested by the European Commission's Scientific Panel to be labeled as a source of $\omega-3$ FA (European Commission, 2005). In conclusions, the diets based on dried whitebait promoted higher levels of DHA in the eggs of laying hens, while the addition of flaxseed oil increased the total $\omega-3$ FA in the eggs, mainly as ALA.

\section{Sensory characteristics}

The panelists observed significant differences in offflavor, fishy flavor, buttery taste and overall acceptability of the boiled eggs (Table 6). Hedonic scores for all attributes, except color, of the eggs from the hens fed the T5 diet (which contained flaxseed oil and dried whitebait) were lower $(\mathrm{p}<0.05)$ than in the eggs from the hens fed the $\mathrm{C}$ diet. There were no differences in all attributes between the eggs from the hens fed the $\mathrm{C}$ diet and the diet with the addition 
of flaxseed oil (T1). Addition of dried whitebait (T4 and 5) resulted in decreased overall acceptability $(\mathrm{p}<0.05)$ compared to the control (C). However, there were no differences in off-flavor, fishy flavor and buttery taste between the T4 and $\mathrm{C}$ diets $(\mathrm{p}>0.05)$. There were no differences $(p>0.05)$ in all attributes between the eggs from the hens fed the diets without FOS (C and T1) and the diets with FOS (T2 and T3). Hedonic scores for off-flavor, fishy flavor, buttery taste and overall acceptability were significantly higher $(\mathrm{p}<0.05)$ in the eggs produced by the hens fed the $\mathrm{C}$ diets than that in the eggs of the hens fed the $\mathrm{T} 5$ diet. However, there was no difference $(\mathrm{p}>0.05)$ between the eggs from the hens fed the $\mathrm{C}$ and $\mathrm{T} 6$ (containing flaxseed oil, dried whitebait and FOS) diets.

The organoleptic quality of the $\omega-3$ eggs tends to be similar to regular table eggs although in some cases panelists are able to detect off-flavors (Milinsk et al., 2003). Koehler and Bearse (1975) first reported lower flavor ratings for eggs produced from hens fed 5\% fish meal, as well as a very slight off-flavor in eggs from hens on a $6 \%$ menhaden oil diet. This remains a problem associated with the commercial production of this type of product. It has been suggested that the use of combinations of antioxidants in the hen's diet could help to suppress these offflavors (Farrell, 1998). However, the sensory evaluation of eggs from hens fed FOS has not been reported before.

Traditionally, feed and feed additives have been thought to be the cause of egg flavor problems (Maga, 1982). The 'fishy egg' aroma compound was identified by HobsonFrohock et al. (1973) to be trimethylamine (TMA). Feed can affect egg taint either by increased dietary TMA levels, by providing precursors for TMA formation by the intestinal microflora or by provision of inhibitors of the endogenous TMA oxidase (Zentek, 2003). The eggs produced by the hens fed fish meal may carry TMA because fish meal contains TMA ranging from 0.04 to $0.07 \mathrm{~g} / \mathrm{kg}$ and TMA oxide ranging from 4.3 to $4.9 \mathrm{~g} / \mathrm{kg}$ (Fenwick et al., 1981; Pearson et al., 1983).

Stewart et al. (1993) summarized the potentially beneficial effects of prebiotics such as leading to antagonism of pathogens, competition with pathogens, stimulation of enzyme reactions, decreases in ammonia and phenol production, and increased colonization resistance. The two main types of fermentation that are carried out in the gut are saccharolytic and proteolytic. Saccharolytic fermentation is more favorable than a proteolytic fermentation due to the acid nature of the resulting products (Gibson et al., 2003). The main end-products of saccharolytic fermentation are the short chain FA: acetate, propionate and butyrate. The end-products of proteolytic fermentation, on the other hand, include nitrogenous metabolites such as phenolic compounds, amines and ammonia (Gibson et al., 2003). An aim of using prebiotics is to increase the amount of carbohydrates that reach to colon. This would increase the amount of saccharolytic fermentation throughout the gut and reduce proteolysis (Gibson et al., 2003). Thus, when there is saccharolytic fermentation, those bacteria do not use as much protein for energy. This may result in less amines, ammonia and branched chain FA (Hahati and Rezaei, 2010). The current results suggest that it may be possible to include flaxseed oil and dried whitebait of high quality, when supplemented with FOS, without encountering major negative differences in consumer preference compared to normal commercial eggs.

\section{CONCLUSIONS}

The production of eggs enriched with $\omega-3$ FA by addition of flaxseed oil and dried whitebait to laying hen diets have been designed to achieve the recommended total $\omega-3$ FA content of $300 \mathrm{mg} / 100 \mathrm{~g}$ egg weight. The results of this study suggest that supplementation with FOS in the diet for the hens may increase egg weight without impairing egg quality such as eggshell breaking strength. Also, the results of this study suggest that a diet with flaxseed oil and dried whitebait supplemented with FOS would be beneficial in terms of obtaining high levels of the various $\omega-3$ FA in eggs

Table 6. Sensory evaluation of the eggs from hens fed diets with flaxseed oil, dried whitebait and/or fructo-oligosaccharide (FOS)

\begin{tabular}{|c|c|c|c|c|c|c|c|}
\hline & $\mathrm{C}^{2}$ & $\mathrm{~T} 1$ & $\mathrm{~T} 2$ & $\mathrm{~T} 3$ & $\mathrm{~T} 4$ & $\mathrm{~T} 5$ & T6 \\
\hline Color & $5.0 \pm 1.5^{1}$ & $4.6 \pm 1.4$ & $4.5 \pm 1.4$ & $4.6 \pm 1.1$ & $5.0 \pm 1.6$ & $4.7 \pm 1.3$ & $5.3 \pm 1.3$ \\
\hline Off-flavor & $4.4 \pm 1.4^{\mathrm{a}}$ & $4.4 \pm 1.2^{\mathrm{a}}$ & $4.5 \pm 1.3^{\mathrm{a}}$ & $4.2 \pm 1.1^{\mathrm{ab}}$ & $3.9 \pm 1.4^{\mathrm{ab}}$ & $3.6 \pm 1.3^{\mathrm{b}}$ & $4.3 \pm 1.3^{\mathrm{a}}$ \\
\hline Fishy flavor & $4.6 \pm 1.4^{\mathrm{a}}$ & $4.5 \pm 1.5^{\mathrm{ab}}$ & $4.7 \pm 1.3^{\mathrm{a}}$ & $4.4 \pm 1.2^{\mathrm{ab}}$ & $4.2 \pm 1.3^{\mathrm{ab}}$ & $3.9 \pm 1.3^{\mathrm{b}}$ & $4.2 \pm 1.5^{\mathrm{ab}}$ \\
\hline Buttery taste & $4.5 \pm 1.2^{\mathrm{a}}$ & $4.4 \pm 1.3^{\mathrm{ab}}$ & $4.4 \pm 1.2^{\mathrm{ab}}$ & $4.4 \pm 1.3^{\mathrm{ab}}$ & $4.1 \pm 1.0^{\mathrm{ab}}$ & $3.8 \pm 1.3^{\mathrm{b}}$ & $4.4 \pm 1.5^{\mathrm{ab}}$ \\
\hline Overall acceptability & $4.7 \pm 1.4^{\mathrm{a}}$ & $4.2 \pm 1.6^{\mathrm{abc}}$ & $4.4 \pm 1.1^{\mathrm{ab}}$ & $4.4 \pm 1.2^{\mathrm{ab}}$ & $3.9 \pm 1.0^{\mathrm{bc}}$ & $3.7 \pm 1.3^{c}$ & $4.2 \pm 1.4^{\mathrm{abc}}$ \\
\hline
\end{tabular}

Samples were evaluated on 7-point hedonic scales ( $1=$ dislike extremely; 7 = like extremely).

${ }^{1}$ Data are reported as average values \pm standard deviation of fifteen panelists evaluating eggs obtained during the final 3 days of the experiment. Each panelist tasted each egg twice. The four samples from each egg were given to the same four panelists.

${ }^{2} \mathrm{C}$, basal diet with $1.5 \%$ soybean oil; T1, basal diet with $1.5 \%$ flaxseed oil; T2, basal diet with $1.5 \%$ soybean oil+1.5\% FOS; T3, basal diet with $1.5 \%$ flaxseed oil+1.5\% FOS; T4, basal diet with $1.5 \%$ soybean oil+1.5\% dried whitebait; T5, basal diet with $1.5 \%$ flaxseed oil+1.5\% dried whitebait; T6, basal diet with $1.5 \%$ flaxseed oil $+1.5 \%$ dried whitebait $+1.5 \%$ FOS.

${ }^{\mathrm{a}-\mathrm{c}}$ Means in the same row with different superscripts are significantly different $(\mathrm{p}<0.05)$. 
without significantly undesirable organoleptic characteristics. However, further work is needed to determine the impact of longer storage periods, abuse in distribution, and different cooking methods for the eggs with sampling a great number of consumers. Some work to determine the mechanism for FOS affects on the egg quality, lipid metabolism and sensory characteristics of the eggs might also be beneficial.

\section{REFERENCES}

AOAC. 1995. Official Methods of Analysis, 16th edn. Association of Official Analytical Chemists, Arlington, VI, USA.

AOCS. 1980. Method Ce-2-66. Official and Tentative Methods of the American Oil Chemists' Society, Champaign, IL, USA.

Aymond, W. M. and M. E. Van Elswyk. 1995. Yolk thiobarbituric acid reactive substances and $n-3$ fatty acids in response to whole and ground flaxseed. Poult. Sci. 74:1388-1394.

Caston, L. J., E. J. Squires, and S. Leeson. 1994. Hen performance, egg quality, and the sensory evaluation of eggs from SCWL hens fed dietary flax. Can. J. Anim. Sci. 74:347-353.

Chen, Y. C. and T. C. Chen. 2004. Mineral utilization in layers as influenced by dietary oligofructose and inulin. Int. J. Poult. Sci. 3:442-445.

Chen, Y. C., C. Nakthong, and T. C. Chen. 2005. Improvement of laying hen performance by dietary prebiotic chicory oligofructose and inulin. Int. J. Poult. Sci. 4:103-108.

European Food Safety Authority. 2005. Opinion of the scientific panel on dietetic products, nutrition and allergies on a request from the Commission related to nutrition claims concerning omega-3 fatty acids, monounsaturated fat, polyunsaturated fat and unsaturated fat. Eur. Food Saf. Auth. J. 253:1-29.

Farrell, D. J. 1998. Manipulation of the fatty acid composition of poultry meat and eggs to meet consumer demands. Proceedings of the 6th Asian Pacific Poultry Congress, 4-7 June 1998; Nagoya, Japan. pp. 58-63.

Fenton, M. and J. S. Sim. 1991. Determination of egg yolk cholesterol content by on-column capillary gas chromatography. J. Chromatogr. A. 540:323-329.

Fenwick, G. R., C. L. Curl, A. W. Pearson, and E. J. Butler. 1981. Production of egg taint by fish meal. Vet. Rec. 109:292.

Flickinger, E. A., E. M. W. C. Schreijen, A. R. Patil, H. S. Hussein, C. M. Grieshop, N. R. Merchen, and G. C. Jr. Fahey. 2003. Nutrient digestibilities, microbial populations, and protein catabolites as affected by fructan supplementation of dog diets. J. Anim. Sci. 81:2008-2018.

Frank, A. 1999. Prebiotics stimulate calcium absorption: A review. Agro. Food Ind. Hitec. 15-17.

Galobart, J., A. C. Barroeta, M. D. Baucells, R. Codony, and W. Ternes. 2001. Effect of dietary supplementation with rosemary extract and $\alpha$-tocopheryl acetate on lipid oxidation in eggs enriched with $\omega$ 3-fatty acids. Poult. Sci. 80:460-467.

Gibson, G. R., R. A. Rastall, and R. Fuller. 2003. The health benefits of probiotics and prebiotics. In: Gut Flora, Nutrition, Immunity and Health (Eds. R. Fuller and G. Perdigón). WileyBlackwell, Oxford. pp. 52-53.

Gibson, G. R. and M. B. Roberfroid. 1995. Dietary modulation of the human colonic microbiota: Introducing the concept of prebiotics. J. Nutr. 125:1401-1412.

Gonzalez-Esquerra, S. and S. Leeson. 2000. Effect of feeding hens regular or deodorized menhaden oil on production parameters, yolk fatty acid profile, and sensory quality of eggs. Poult. Sci. 79:1597-1602.

Gonzalez-Esquerra, S. and S. Leeson. 2001. Alternatives for enrichment of eggs and chicken meat with omega-3 fatty acids. Can. J. Anim. Sci. 81:295-305.

Hahati, H. and M. Rezaei. 2010. The application of prebiotics in poultry production. Int. J. Poult. Sci. 9: 298-304.

Hamilton, R. M. G. 1982. Methods and factors that affect the measurement of egg shell quality. Poult. Sci. 61:2022-2039.

Haugh, R. R. 1937. The haugh unit for measuring egg quality. United States Egg Poultry Magazine 43:552-573.

Hobson-Frohock, A., D. G. L., N. M. Griffiths, and R. F. Curtis. 1973. Egg taints: Association with trimethylamine. Nature 243:304-305.

Koehler, H. H. and G. E. Bearse. 1975. Egg flavor quality as affected by fish meals or fish oils in laying rations. Poult. Sci. 54:881-889.

Maga, J. A. 1982. Egg and egg product flavor. J. Agric. Food Chem. 30:9-14.

Milinsk, M. C., A. E. Murakami, S. T. M. Gomes, M. Matsushita, and N. E. Souza. 2003. Fatty acid profile of egg yolk lipids from hens fed diets rich in n-3 fatty acids. Food Chem. 83:287292.

National Research Council (NRC). 1994. Nutrient Requirements of Poultry. 9th ed. National Academy Press, Washington, DC, USA.

Park, P. W. and R. E. Goins. 1994. In situ preparation of fatty acid methyl esters for analysis of fatty acid composition in foods. J. Food Sci. 59:1262-1266.

Park, S. O. and B. S. Park. 2012. Effect of feeding inulin oligosaccharides on cecum bacteria, egg quality and egg production in laying hens. Afr. J. Biotechnol. 11:9516-9521.

Parpinello, G. P., A. Meluzzi, F. Sirri, N. Tallarico, and A. Versari. 2006. Sensory evaluation of egg products and eggs laid from hens fed diets with different fatty acid composition and supplemented with antioxidants. Food Res. Int. 39:47-52.

Pearson, A. W., N. M. Greenwood, E. J. Butler, C. L. Curl, and G. R. Fenwick. 1983. Fish meal and egg taint. J. Sci. Food Agric. 34:277-285.

Scheideler, S. E. and G. W. Froning. 1996. The combined influence of dietary flaxseed variety, level, form, and storage conditions on egg production and composition among vitamin Esupplemented hens. Poult. Sci. 75:1221-1226.

Scheideler, S. E., G. Froning, and S. Cuppett. 1997. Studies of consumer acceptance of high omega-3 fatty acid-enriched eggs. J. Appl. Poult. Res. 6:137-146.

Shapira, N., P. Weill, and R. Loewenbach. 2008. Egg fortification with n-3 polyunsaturated fatty acids (PUFA): Nutritional benefits versus high n-6 PUFA western diets, and consumer acceptance. Israel Med. Assoc. J. 10:262-265.

Souza, J. G., F. G. P. Costa, R. C. R. E. Queiroga, J. H. V. Silva, A. R. P. Schuler, and C. C. Goulart. 2008. Fatty acid profile of eggs of semi-heavy layers fed feeds containing linseed oil. Braz. J. Poult. Sci. 10:37-44. 
Stewart, C. S., K. Hillman, F. Maxwell, D. Kelly, and T. P. King. 1993. Recent advances in probiosis in pigs: Observations on the microbiology of the pig gut. In: Recent Developments in Pig Nutrition (Eds. P. C. Garnsworthy and J. Wiseman). Nottingham University Press, Nottingham, UK. pp. 51-77.
Yildiz, G., P. Sacakli, and T. Gungor. 2006. The effect of dietary Jerusalem artichoke (Helianthus tuberosus L.) on performance, egg quality characteristics and egg cholesterol content in laying hens. Czech J. Anim. Sci. 8:349-354.

Zentek J. 2003. Egg taint - A problem of practical importance. Lohmann Information 28:1-4. 